\title{
A Performative Approach To Women And Power During The Roman Republic
}

\author{
Mujeres y PODER EN LA ROMA REPUbliCANA: \\ UN ENFOQUE PERFORMATIVO
}

Coré Ferrer-Alcantud

Universitat Jaume I

Recibido: 23/05/2018 Evaluado: 29/05/2018 Aprobado: 30/05/2018

ABSTRACT: The objective of this paper is to investigate the involvement that women in Republican Rome could have had in matters alleged to be enjoyed exclusively by men, concerns such as politics and finances, with the ulterior aim of revealing actual social realities, formerly ignored and disregarded. Previous studies focused largely on women's domesticity, fertility, and the preservation of a stainless behavior as a result of the exempla outlined by ancient authors such as Livy, Vergil, Plutarch, and Appian, male writers who lived on the edge of time between the precepts of the Republic and the brand-new outset of the Principate. By using an innovative approach based on Judith Butler's performativity, we will be able to explore Roman women's identities and their closeness to an actual but traditionally obscured power.

Keywords: performativity, alterity, identity, gender, power, Roman Republic, exempla.

RESUMEN: El objetivo de este artículo no es otro que el de investigar la implicación que las mujeres de la Roma republicana podrían haber tenido en asuntos que, supuestamente, solo eran disfrutados por los hombres, como son la política o las finanzas, con la finalidad de descubrir realidades sociales auténticas que habrían sido ignoradas hasta 
ahora. Algunos estudios previos se han centrado principalmente en la domesticidad de las mujeres, en su fertilidad y en la persistencia de un comportamiento inmaculado como resultado de los exempla expuestos por autores como Livio, Virgilio, Plutarco o Apiano; escritores masculinos que vivieron entre los convulsos últimos años de la república y los comienzos del reciente principado. Desde una metodología innovadora basada en la teoría de la performatividad de Butler, nos adentraremos en las identidades de las mujeres romanas evidenciando su proximidad a un poder tradicionalmente invisible y, sin embargo, real.

Palabras clave: performatividad, alteridad, identidad, género, poder, República romana, exempla.

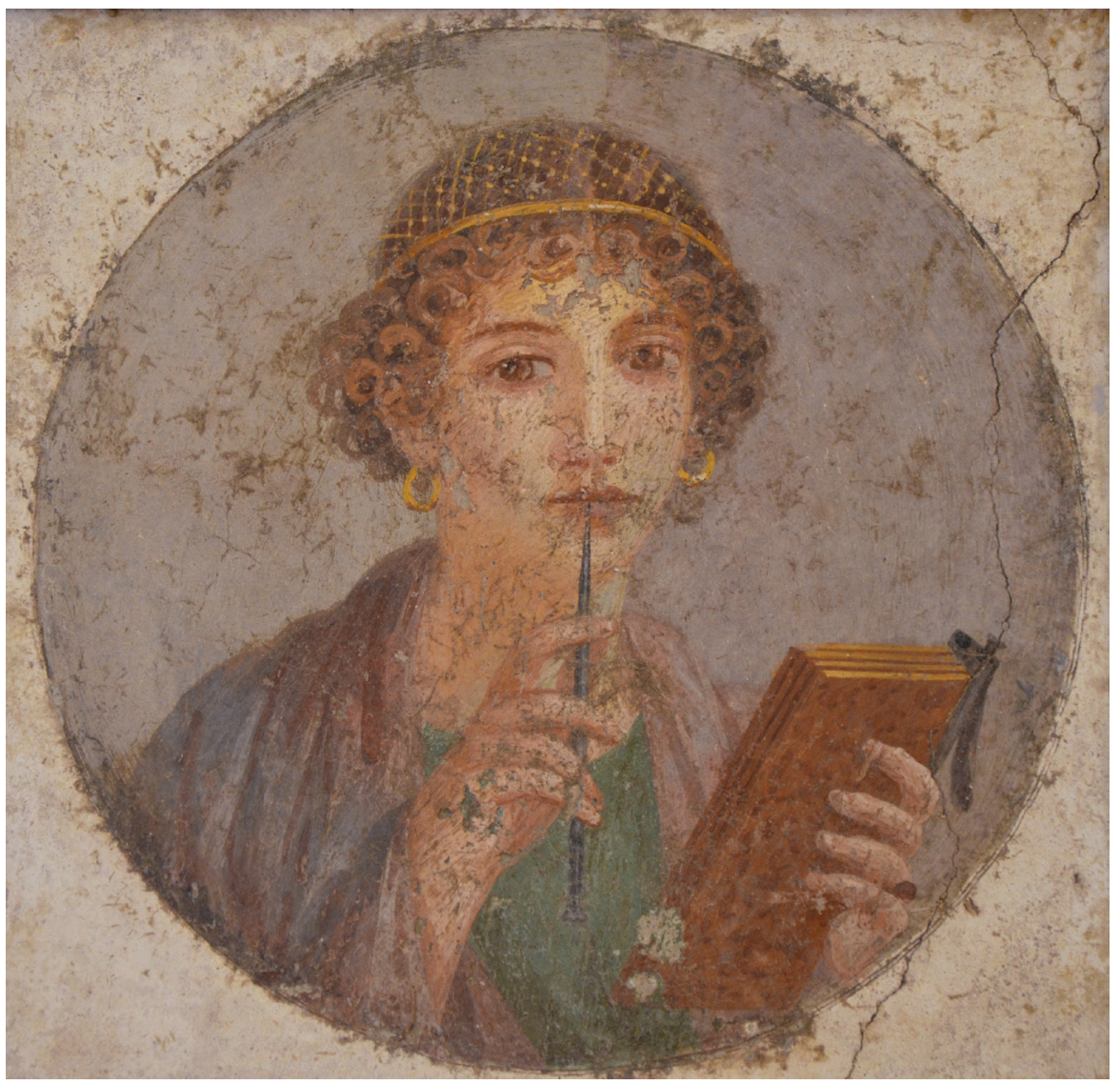

Fig. 1. Woman with stylus, 1st century AD, Pompeii. National Archaeological Museum of Naples, inv. no. 9084. 
"The painter is so far limited that it is only through the mask of the body that he can show us the mystery of the soul; only through conventional images that he can handle ideas (...) striving to render, by visible form or colour, the marvel of what is invisible, the splendor of what is not seen"

Oscar Wilde ${ }^{1}$

\section{INTRODUCTION}

$\mathrm{D}$ espite "male-Rome" was indeed the same as that for women, the latter were not portrayed in History as often as men, nor did they participate in its writing. In this regard, the woman in the picture shown above has been largely identified as Sappho, as if any women in Rome could have ever been depicted as an educated and instructed person apart from the Greek poet, nor in an attempt to write. This well-known Pompeian fresco let us visualize how deeply rooted are the thoughts about ancient women who could actually have written their own histoy, in addition to how natural, real, and imposed is the silence on Roman women. Moreover, with not much direct information elaborated by women in terms of textual sources, we have no alternative but to rely on those written by men "so far limited that it is only through the mask of the body", through a well-established performative identity, "that [they] can show us the mystery of the soul". Hence, an ideal and fragmented reality, since the mask that is the body has been fabricated in order to fulfil a role based on procreation and domesticity. How different would the history of ancient Rome be if we could have gathered women's own writings?

Due to this lack of straightforward information, an approach is required in order to elucidate what really happened with women in the past, what things inspired them, which were their interests and habits. Hence, feminism and social history became essential approaches for these studies. However, historiography produced by feminism has become eventually biased regarding men's exclusion, even though women were finally integrated in the whole traditional history. Moreover, it actually ended up segregating them in an isolated group of studies that diminished further tangible results. In this regard, a brand-new inclusive approach will emerge in the 90s, leading the studies to the sphere of gender. Since then, gender historians have tried to analyze a large amount of literary and other kind of material sources based on the observation that the Romans themselves shaped, ancient minds who used to agree with the idea of a society divided in two genders according to their biological sex. This approach was meant to bring to light all social interrelations among individuals and collectives within Roman society, thus studying men and women behavior in order to find out how and why interact the way they do. Furthermore, this formula allowed to research on women as a social group and not only within

1. O. WildE: Intentions, Bretano's, Nueva York, 1905, pp. 146. Extraído como formato digital de https:// archive.org/details/cu31924079601617 
a domestic context, but also in the sphere of female private and public religion, prostitution, education, abortion and pregnancy, magic, and many other topics which seemed to be roughly known until gender studies appeared and started to focus on women's acts and interactions with men, those who they apparently considered the other half of the population.

Thereunder, however, it has been observed that gender approach has limitations as well, since it focuses on the relationships between men and women as if they were the only two existing genders, divided indeed corresponding a patriarchal society that has given women a specific role and a detailed outerdepiction -women as wives, mothers, and praiseworthy widows-, and leaving little room for dredging up reality. In other words, gender used as a method could lead to inconsistent results, since what would be actually assuming is what Romans wanted us and further generations to believe. That is, an ideal society split in two main gender archetypes with specific and well-defined roles, which were intended to keep population controlled as well as to maintain their traditions. As Romans narrated their history in their own terms, researching according to these standards would lead our investigations to the immortalization of this clever propaganda that is the tall tale of Rome. In this sense, the noticeable silence of women -likely mothers, sisters, and daughters of all great men in History- tells us more than we could have imagined.

In essence, old-style scholarship use to rely upon the furtherance of a literature that boosts the traditional Roman values by displaying women on her role as faithful, honorable housewives, and reprehend those who walk away from the stereotypical path that they should be following instead. Nevertheless, some of these sources also reveal the existence of some women who actively operate in the middle of political affairs of State along with men or even on their own. In this sense, some contradictions have been set up explicitly showing a society that tries to relegate women to domesticity, while trying to preserve their decency by founding institutions based on a compromising corpus of legislation. Were these women as virtuous and pure, or were they as wicked and immoral as shown by some men in literary sources? Or, perhaps, were the latter the actual manners and reality of some of the women living during the Roman Republic, women challenging and weakening a non-inclusive society?

We would like to use this paper as a means to an end. The aim this paper pursues is either to grasp and understand the truth about women during the Roman Republic while unveiling how involved they were in politics. With reference to their political participation, we will try to show evidence of a feasible chase and success regarding their own self-awareness, not to be confused with some factual independence prone to these matters. ${ }^{2}$ In his regard, innovations in the analysis of Roman women's behavior and social setting are crucial, as this is a field that may still be not explored in its whole, nor has it been studied in the most precise manner. By providing an approach that overthrows the

2. J. Gardner: Women in Roman Law \& Society, Croom Helm, Londres, 1987, p. 1. 
limitations of former methods, we would be able to dig deeper into Roman women's genuineness, both aim and challenge of every historian.

Collaborations between different scientific disciplines along with the ones regarding History per se, could improve not only the development of new analytical trends, but also provide a renewed understanding of certain materials and sources that have already been extensively studied. Accordingly, the emergence of new research perspectives could contribute to the establishment of brand-new methodologies, such as the one we are going to display and work with in this paper. Thus, not only an accurate knowledge of the sources regarding women would be needed, but also an innovative spirit and confidence on our own contemporaneity, since the framework embracing every researcher usually gives them an exceptional environment to design plans, ideas and deep-thinking. In other words, a context, most of the times brimming with relevant structural and social changes, would be turned into a spawning ground for researching on actual women and the connotations of gender, and the times we are living in at this moment, where seemingly women have regained their voices, could set in motion an evolution -or revolution- a propos gender studies. ${ }^{3}$

\section{IDENTITY AND ALTERITY: A PERFORMATIVE APPROACH TO ROMAN WOMEN}

Obtaining the materials and sources that could be useful to us as straightforward testimonies of a Roman past in their fullness is not only challenging, but unachievable, which is why History will always be fragmented. However, novel approaches, along with the development of both experienced and new research fields, could end up giving visibility to a past that, despite being incomplete and explored in wreckages, will definitely continue to enrich historiography in an endless way. Such is the case of the approach we are going to introduce in this paper, a method we developed conjoining the works of Goffman, Levinas, Derrida, and Butler, all major intellectuals who tried to provide answers to identity, its formation, and its accurate meaning and purpose.

Although identity as an instrument for scientific study is not new in social sciences, it is still a novel method in the sphere of ancient history. However, a relatively recent study by Professor David Mattingly, from the University of Leicester, shows a survey of the use of the terms "Romanization" versus "identity" within paper titles and abstracts written between 1995 and 2007, observing an intensification of identity works replacing those with reference

3. e.g. Time's Up Movement, against sexual assault in the workplace that has been joined but many actresses and movie professionals, more information: https://www.timesupnow.com/; or the protests all over Spain against the court sentence in the gang rape case known as La Manada lawsuit, becoming relevant internationally; retrieved from https://www.cbsnews.com/news/spain-la-manada-sexual-abuseconviction-pamplona-protests-assault-rape-laws/ 
to Romanization. ${ }^{4}$ Broadly speaking, it should be noted that the concept of Romanization, as an analytical approach which poses Romans as protagonists, has been replaced by a more fluid tool that sets the Other as the relevant character. In this sense, identity as an instrument of investigation has transcended successfully in the study of the history of Rome, something perceptible in the increase of works in this regard, where configuration and interaction of identities are considered decisive in the development of every past civilization.

Due to the space provided for this paper, we cannot extend with regard to identity in depth. However, we would like to outline the main features of the concept in order to prove its effectiveness. First, identity could be acknowledged as a social tool which allows humans to identify individuals as well as collectives within society, since one or the other meet specific standards that make them noticeable. Accordingly, and this is how we will be able to recognize its expressions in any of the Roman realities, identity works in a twofold way that is to match society -in a sense of community and belonging-, and to diverge from it or the collective -in agreement to uniqueness and individuality-. Secondly, we could define identity as a receptacle in need of a set of attributes or characteristics in order to shape it:

"Identity may be defined as the collective aspect of the set of characteristics by which something or someone is recognizable or known. These may be behavioural or personal characteristics, or the quality or condition of being the same as something else. This sense of collective similarity among entities, be they objects or individuals, implies that the very notion of identity also depends upon opposition through a contrast with something else."

These characteristics are usually those regarding age, status, wealth, ethnicity, and, obviously, gender. Therefore, its configuration will depend on this cluster of features which will define any individual and the way they are going to be recognized or read within society. Hence, identity helps us track down and understand people, however it also means that a contrast or opposition is needed in order to create and define any identity, as it is shown in the fragment above. This is known in the fields of philosophy and sociology as "otherness" or "alterity", which is in essence the observance of the Other's attributes and their decisive effect on the construction of the Self.

In order to clarify the ideas presented, we will give a concise description of the thesis that we found useful for the development of our method, the ones expounded by Erving Goffman, Jacques Derrida, Emmanuel Levinas, and Judith Butler. On the one hand, Goffman's theor $y^{6}$ addresses the individual as an actor,

4. D. J. Mattingly: Imperialism, Power, and Identity: Experiencing the Roman Empire, Princeton University Press, 2011, pp. 208-209.

5. T. Hodos: «Local and Global Perspectives in the Study of Social and Cultural Identities», Material Culture and Social Identities in the Ancient World, Hales y Hodos (eds.), Cambridge University Press, 2009 , p. 3.

6. E. Goffman: La presentación de la persona en la vida cotidiana, Amorrortu, Buenos Aires, 1993. 
thus identity being the result of the performance of a role, as actors in a play wearing masks, that in this sense could be interpreted as the attributes shown above, hence artificial characteristics self or socially imposed, in order to read and read as part of a specific society. On the other hand, Derrida highlights the importance of "deconstructing" deep-rooted social foundations, as he did concerning linguistics and some particular terms, e.g. the concept "differànce", a neologism crafted by this philosopher which alludes to the linguistic opposition and contrast in terms of exclusion. In this regard, the difference coined by Derrida is shown as the primeval source concerning the construction of all words and thus our society, as oppositional language is both the main supplier and the highest source of power. As for Levinas' work, we must say he coined the terms "otherness" and "alterity" by stating that the formation of the Self will always depend on an Other, since identity needs alterity to design and confirm its own nature. ${ }^{8}$ This was a revelation, considering that until then researchers used to consider identity as the construction of the Self, while the Other based their attributes on the observation of the first. However, Levinas aimed to demonstrate that is in fact the Other who truly construct the Self, as the latter creates their own identity by opposition to those elements they do not wish for sharing. As a final point, we will expose Butler's theory of Performativity, on which she concludes that gender is artificial, a social imposition resulting from a cultural elaboration and its reiteration over time. Thus, gender is not innate nor natural, but only an attribute of many of the ones forming identities, and its performative representation can be traced in every historic framework. Butler has established a multidisciplinary line of research based on fields such as philosophy, sociology, and linguistics, therefore materializing a convenient approach to different investigation grounds. In this sense, history could profit from performativity by adapting Butler's theory, since gender is part of every society, modern and ancient, and therefore can be witnessed in all historic periods to be eventually scrutinized as any other research component.

She has not ceased publishing concerning gender and focusing on a proper understanding of its meaning, the bodies, and their interaction and fitting within society, and consequently enabling the conception and development of her renowned Performativity theory. As we stated above, this theory suggests that gender is essentially a deception, a device socially assembled that has been created through performative acts, namely both speech acts and non-verbal communication. By performing or acting in a certain way, people can be labeled within a specific gender which, additionally, only meets two accepted alternatives, to be either a woman or a man. In her works, Butler hits gender from below and is capable of proving its cultural, hence illusive, composition. In addition, her work has been of assistance in the development of the so-called Queer theory, ${ }^{9}$

7. J. DeRrida: Writing and the Difference, University of Chicago Press, 1978.

8. E. Levinas: Totality and Infinity, Duquesne University Press, Pittsburgh, 2011.

9. J. ButLen: Gender Trouble: Feminism and the Subversion of Identity, Routledge, Londres, 1999, pp. vii. 
concept that opposes to the fictions of a society that revolves around a deeprooted gender binary. Among her several works on performativity, ${ }^{10}$ we have chosen those where Butler reconsiders gender, as these will be useful in order to develop a worthwhile performative approach that evaluates accurately the ancient sources. In Gender Trouble: Feminism and the Subversion of Identity, ${ }^{11}$ the philosopher essentially censures one of the central conventions of feminism that there is an existent identity -women's or gender female identity-. Clearly basing her theory in the works already mentioned such as the ones of Derrida and Levinas, ${ }^{12}$ Butler claims that concepts such as "woman" or "female"13 are nothing but identity attributes, thus working in the same way as ethnicity, age, class, and even sexuality, and not an identity per se.

Indeed, Butler has confirmed that gender is nothing but a cultural lie, an artificial device that aims to segregate people into a dichotomy based on their biological sex and this can only happen through performative acts needed to play accordingly to their legitimate role within society. In order to demonstrate her theory, Butler has focused on remarking the subversive acts that push the boundaries of performativity, of what is traditionally recognized as appropriate for one gender and the other, revealing additional ways of being oneself in those threatening a prearranged society, those who wriggle away from binarism. In this regard, the effectiveness of this approach could likewise meet Roman society, as these subversions can be observed not only in what we know as tradition, but also in politics, law, and other more abstract social features culturally destined to constrain freedom. Hence, we should categorize performativity as the ultimate tool for social control, wiping out uniqueness through subjugation in different historic eras.

As we stated earlier, identity is shaped through attributes such as gender, status, ethnicity, religion, age, etc., in order to become intelligible to themselves and to the overall society. This is how a person with a specific identity is placed in the socio-historical context where they belong, always satisfying the guidelines of the performative discourse that placed them there in the first place. This process follows the same pattern at all times, whatever its historical framework: a discourse or message is launched as a statement to be subsequently preserved through repetitions, iterations that subordinate a particular subject or group to those holding the highest authority, the ones who formulated and spread the performative discourse in the first place.

For the performative discourse to be finally imposed, the subject that is born in a disguised and deceitful way, reached this specific identity through

10. J. Butler: The Psychic Life of Power. Theories in Subjection, Stanford University Press, 1997; «Foucault and the Paradox of Bodily Inscriptions», The Journal of Philosophy, Vol. 86, no. 11, 1989, pp. 601-607; «Performative Acts and Gender Constitution: An Essay in Phenomenology and Feminist Theory», Theatre Journal, Vol. 40, no. 4, 1988, pp. 519-531; «Sex and Gender in Simone de Beauvoir's Second Sex», Yale French Studies, no. 72, 1986, pp. 35-49.

11. J. ButLer: Gender Trouble: Feminism and the Subversion of Identity, Routledge, Londres, 1999.

12. E. LeVinas, 1977; J. DerRida, 1989.

13. J. Butler, 1999, pp. xxix. 
symbolic social rules that give them comprehensibility towards society: the individual is understood by the community, and the repetition of their own imposed and artificial self is required for the maintenance of managed social interactions and for the immortalization of the performative discourse for social control. In terms of applicability and as an example, gender identity discourses in Rome were mainly based on rules, ritual practices, moralizing stories, tradition, standards, and laws that maintained control over the "feminine Other", who occasionally could threaten the pillars of Roman-ness by subverting the performative discourse. For instance, masculinity or male identity is traceable during the last stages of the Roman Republic due to patriarchy, as well as is based on the power of maleness that is configured in opposition to what the Other should be. In this sense, men had a tangible domain of what we call "institutional politics", thus having a prominence in these affairs would be a mark of maleness, hence men's identity as such. ${ }^{14}$ In this regard, the use of feminizing insults against male political opponents was a common practice, since men would recognize some attributes imposed to women and later repeated over the centuries, as softness in speaking, making undulating gestures, or modulating their voice in a certain way, hence characteristics of the Roman female identity. Accordingly, these elements of a "womanized" Other will be used to undermine men's maleness in order to humiliate them and implying their political incapacity. Romans, therefore, were aware of the existence of gender as identities exist, although they are not explicitly cited in this way: women, foreigners, slaves... These are just a few identities coexisting in Rome, which the Roman cleverness helped to craft in an attempt to shape their own central identity based on maleness, citizenship, wealth, and stoicism. Consequently, our main task will be to identify the elements that help in the construction of gender identities in order to classify them and establish their starting point. In order to do so, we need an approach based on performativity, a method consisting of the observation and tracking of State-regulated iterations transformed into naturalized requirements for the Roman women. Once the inconsistencies of an imposed gender performativity are detected by these women, they will subvert the controlling discourse and transgressions in sources will take place. As a result, these ruptures on the primeval and constricting message will finally be spotted by us as researchers. These subversions are usually caused by external events within the historic framework and its society, thus in conformity with every change each period could have experimented.

Using performativity as an approach to research on Roman identities, we will be able to distinguish reality from the performative acts carried out by the

14. C. A. Williams: Roman Homosexuality: Ideologies of Masculinity in Classical Antiquity, Oxford University Press, Nueva York, 1999, 125-59; E. Gunderson: Staging Masculinity. The Rhetoric of Performance in the Roman World, The University of Michigan Press, Ann Arbor, 2000; M. W. GLEASON: Making Men. Sophists and Self-Representation in Ancient Rome, Princeton University Press, Princeton, 2008, pp. 62 et seq. 
institutional, thus male, politics. By spotting subversive practices fulfilled by women who did not agree with an identity based on a prefabricated gender, which was being imposed through the iteration of customs and moralities. Our aim is not an exhibition of sources showing roles and stereotypes that ostracize republican women to a domestic life revolving around fertility, but to trace, record, and display those performative expressions that have made us believe that this was precisely the veracity of all women. We aim to review Roman republican politics by taking women into account as relevant participants on several events in this regard, basing our thesis on gender identities and their failures. As a result, we will be able to observe a "female-thus-noninstitutional power" silenced by men through performative acts and operates in the following pattern: a message or discourse is created; repeating it will eventually install within society some normative practices; as consequence of such iterations, the discourse evolves into an apparently naturalized and intrinsic element of society, e.g. tradition itself.

"I would suggest that performativity cannot be understood outside of a process of iterability, a regularized and constrained repetition of norms. And this repetition is not performed by a subject; this repetition is what enables a subject and constitutes the temporal condition for the subject. This iterability implies that "performance" is not a singular "act" or event, but a ritualized production, a ritual reiterated under and through constraint, under and through the force of prohibition and taboo, with the threat of ostracism and even death controlling and compelling the shape of the production, but not, I will insist, determining it fully in advance"15

Using the premises of Butler's theory of performativity, we are able to observe how the conventional Roman woman will be transformed into multiple women who comprise heterogeneous identities, which only confirms the mutability of gender and its morphology based on performance. Gender identity, in this case the singular and ideal Roman woman, is in fact a picture crafted by a system that seeks to impose, reiterate, and finally naturalize a fabricated and artificial condition within society. And this process, meaning inserting a discourse, repeating it, and eventually normalizing it, is what Butler calls performativity. Hence, the purpose of a performative discourse is, basically, the creation of a specific and well-schemed reality through language and actions. Therefore, following this pattern we will be able to detect the steps that any performative discourse follows when studying the social interrelations in Roman cosmos, as well as the exclusions which will be identified as alterities aiming a predominant identity.

In order to not dwell further on these matters, we have created the following table:

15. J. Butler: Bodies That Matter. On the Discursive Limits of "Sex", Routledge, Nueva York, 2011, p. 60. 


\begin{tabular}{|c|c|c|}
\hline \multicolumn{3}{|c|}{ PERFORMATIVE DISCOURSE APPROACH } \\
\hline Creation and Imposition & Repetition & Naturalization \\
\hline $\begin{array}{l}\text { From an excluding } \\
\text { position power, a } \\
\text { discourse that attempts } \\
\text { to be imposed within } \\
\text { society is produced. } \\
\text { Accordingly, this } \\
\text { message will be spread } \\
\text { by what we will call “tools } \\
\text { for perpetuity”. } \\
\text { (e.g. Roman tradition, } \\
\text { mores, law, religion, etc.) }\end{array}$ & $\begin{array}{l}\text { In order to be socially } \\
\text { imposed, the primeval } \\
\text { discourse must be constantly } \\
\text { reiterated via “performative } \\
\text { instruments”, which depend } \\
\text { on the previously mentioned } \\
\text { perpetuity tools. } \\
\text { (e.g. marriage, women's } \\
\text { guardianship, monogamy, } \\
\text { constricting language, using } \\
\text { literature, art, even clothing } \\
\text { as transmitters, etc.) }\end{array}$ & $\begin{array}{l}\text { After years of ceaseless } \\
\text { discourse repetition, it will } \\
\text { finally normalize within society. } \\
\text { Eventually, this artificial truth } \\
\text { will become an innate and } \\
\text { natural reality. } \\
\text { (e.g. gender identity, female } \\
\text { roles and stereotypes, } \\
\text { heterosexuality, and } \\
\text { feebleness will be taken as } \\
\text { inborn features of Roman } \\
\text { women) }\end{array}$ \\
\hline
\end{tabular}

Fig. 2. Descriptive table summing up the approach disclosed throughout this paper.

Summarized in the table above, the tracking path regarding any performative discourse will always follow an "imposition-repetition-standarization" process.

In this sense, unraveling why women were excluded legally and traditionally from institutional politics depend on the configuration of the identities in the Roman republic. In order to do so, we believe that ruptures and subversions should be located and distinguished from the predominant performative message, since there is an actual presence of "political" women who subverted their performative domestic destiny, thus shaping their identity out of what we can now see as a social role and hence a stereotype. Nevertheless, men, as the ones who hold institutional power, will try to fix these ruptures through a twofold procedure that depends on the relevance and consequences that every political female subversion may imbue. The customary suggested solutions handled by these men were usually two: first, silencing women; then, usurping the latter's subversive acts. On the one hand, men in power used to ignore the rupture that women created by muting them for the sake of tradition and mores, that is to say for the benefit of their identity role pattern in a smartly designed society where every actor -thus, every performer- has their precise place and specific tasks to assume. On the other hand, if those men could not be successful at suppressing these women's insubordinate acts, they would 
take over these subversive actions in order to, afterwards, adapt them as part of a brand-new performative discourse which would include these ruptures as apparent social needs and turning them eventually into theirs. By way of example, this pioneering approach would help to accomplish a deeper investigation on the ius trium liberorum, since it could be seen as an appropriation that one of these powerful men -in this case, under the rule of princeps Augustus- implemented in order to take ownership on a long lasting request purported by republican women, here interpreted as a subversion of a gender identity imposed by the leading performative discourse, which is in turn based on a fictional tradition.

Therefore, it is our intent to show both kind of ruptures, although devoting greater attention to those that cannot be controlled and will make necessary the elaboration of new means to perpetuate the performative message of social control. In this regard, one of the most effective performative instruments in Rome were the exempla, tales found in the sources as illustrations of either proper and unacceptable behavior of the formerly two established genders, men and women. Our main interest concerning exempla revolves around the idealization caused by the repetition over centuries of a discourse that praises a definite and very explicit republican women's identity. Ancient authors such as Livy and Plutarch were well-known acolytes of this genre, which ultimate goal could be excluding inconvenient alterities in order to perpetuate social control by the hand of the dominant identity, as we stated earlier, a Roman male citizen with political ambitions, performatively excluding Others, social minorities that paradoxically allow the exaltation of those in power. Summing up, an approach based on Levinas' alterity and Butler's performativity could explain the reason why a few women appeared sporadically in the ancient sources linked somehow to political affairs. Moreover, this method trails successfully the ruptures that evidence a deep-seated and recurrent performative message.

Gender performativity is, henceforth, a task needed in order to emphasize that the depiction of the republican women lasts until modern times and yet we still have to clarify that changes within the Roman Republic should have affected women as well as men. Thus, women evolved in a society which was constantly moving, as they did as part of a variety that imbued several and divergent identities also mutating along with the political events. This means that identities are not static and depend tightly on the observation of the Other from the perspective of the subject of domination. The phenomena of identity and their inseparable alterity may respond to the location of plural women who might have been interested in a field such as politics from which, they are excluded with ferocious insistence with a performative discourse.

To put it briefly, knowing how gender or "female" identity was built, as a cultural thus fictional construction, would help to explain the real interrelations existing among Roman society, while performativity would facilitate exposing 
the actual meaning hidden behind merging concepts such as "woman" and "female", or even "power", as we will be able to detect subversions not only within texts and documents considered as regular literary sources, but also in other kind of material traces that let us envision the iteration and normalization that performativity provided to Roman society overall ${ }^{16}$.

\section{EXEMPLA: REPRESENTATIONS OF A PERFORMATIVE REALITY}

To achieve their objectives, some powerful men, that is, institutional rulers and legal representatives of power, will develop a constrictive legislation based on rules that will make Roman women, considered as a group within what is a standardized female conception, to be constituted as citizens in the social fabric, although the rest of legal aspects ensure their relegation in the background, thus legally required to keep a significant distance from the spaces and activities of the gender that is constructively opposite, the male gender.

For example, the wealth obtained by women via their male relatives' inheritance, that given in the form of dowry, or that one obtained as a salary, empowered some women to grasp a power located in the public domain, where only men could exercise and perform their duties as active members of the institutional politics.

In a convoluted structure were social tools were needed by male oligarchy of the Roman Republic -as we have already noted, tools such as marriage, law, mores, religion...-, in order to hold power and social control over women and other minority groups, this approach would also show clearly which messages and depictions are truly real, while others will be exposed as mere positive and negative female exempla.

Accordingly, there is a strong literary tradition concerning aristocratic women related to several political events, even undertaking successfully certain achievements regarding diplomatic affairs and legislation. Tradition is an important element to bring light on future institutions, but taking into account that this precise tradition is nothing more than a performative discourse constructed to control society by the establishment of role-identities, we can determine that the aim of those asserting the message is to use it as political propaganda. Therefore, tradition forbids the participation of women in institutional politics, which requires voting, holding office positions as magistrates, and being part of the army; ${ }^{17}$ all this due to the use of several tools of perpetu-

16. e.g. sources such as Greek female sculptures used in a performative way to introduce behavioral patterns as if they were Roman's own traditional guidelines, in A. ALEXANDRIDIS: «Neutral Bodies? Female Portrait Statue Types From the Late Republic to the Second Century CE», Material Culture and Social Identities in the Ancient World, Hales y Hodos (eds.), Cambridge University Press, Cambridge, 2009, pp. 252-279.

17. D. 50.17.2. 
ity and performativity instruments that allow to preserve the discourse Roman women's identity, as well as some new instruments added such as the use of speech as a constant reminder of polar prohibitions, thus segregation through otherness, stated in sources as the so-called infirmitas and leuitas animi of women. ${ }^{18}$

Despite the iterated discourse against women interfering into politics, some will break down the performative message that throws the paradigm of the proper female behavior and it can be found in either literary or material sources. Hence, these ruptures reveal the falsehoods carried out by a fictional tradition. Indeed, some of these breaks and performative-message subversions are related to what we have are calling along this paper as "female politics", politics made and influenced by women that were not allowed to participate actively in it, but managed to make it anyway.

Precisely, we find many of these political women in the works of the Roman writer Livy, although legendary as Lucrecia, a whole paradigm of virtue and also cause of Roman monarchy's death, ${ }^{19}$ or the plebeian Verginia who apparently took down the decemvirs' rule unkowingly. ${ }^{20}$ Although not all is fabled, the remains of a more or less realistic facts will not correspond in any case with the elaborate roles played by its characters, since they are fabricated stereotypes that serve as a social example for women as the proper Roman female identity, and moreover as examples to explain how some regimes were demolished by using feeble models of women as symbols as well as trigger factors. In fact, we can agree that Livy's "political women" could have been created to spread a performative speech elaborated by Augustus in order to introduce a new regime and a moralistic legislation, which pleads for the chastity of women, adducing to a return to a long-gone tradition and lost appropriate customs. Indeed, customs and tradition are tools of a discourse created specifically in order to achieve control of Roman society as a whole, which also generates artificial identities based on opposition and otherness.

Leaving the "good" women aside, we must pay attention to subversions and ruptures reflected in Livy as negative exempla, which statements are part of an antithetical discourse where women are shown as inappropriate political leaders and mutineers as the ones seeking to counteract the Oppian law. In words of Cato the Elder, Livy will display his modus operandi concerning women who were involved somehow in political situations such as the above mentioned, making use of them as vessels of wickedness and immorality. ${ }^{21}$ Around the 3rd century BC, in the context of the Punic Wars, the influence and dissemination of Greek thought begins to be integrated into the Roman intellectual fabric merging with Stoicism, the prevailing philosophical trend. The austerity

\footnotetext{
18. Livy, 34.7.

19. Livy 1.57.7-60.

20. Livy, 3.44-3.58.

21. Livy, 34.1.1-8.3; Val. Max., 9.1.3; Tac., Ann., 3.33-34.
} 
caused by these wars, as well as the following financial restoration and restoration, will affect women who, contrary to what domesticity and normative gender established, will reach the Forum -an institutional place, hence a male space - with the aim of persuade the Senate to repeal a law against sumptuousness of women within the city of Rome, the lex Oppia instituted in 215 until $195 \mathrm{BC}$, the year of its repeal.

In order to give more information about women's financial participation in the affairs of the State, we must pay attention to their connections an increased personal and collective power held in the hands of matronae during the Roman Republic. Indeed, women used to increase their influence and participation after periods resulting from war, which lacked of men to release Rome from its own demise. By using a performative method, we can realize that the petition of women to dismantle a law that forbids them to dress in a certain way and hold a specific amount of wealth, ${ }^{22}$ carries information of great relevance. In this sense, women who protested against a republican system that constrained them to not be the women they wanted, are the ones who helped recovering with their own wealth the economy of Rome after the disaster of the battle of Cannae in 216 BC. In this regard, we will be able to notice how wealth, given as dowry as well as obtained as a salary, gives public power to women in a sphere that was destined to men according to the performative discourse of Roman tradition. In this sense, we should recognize these women as exceptional investors in a republic that, devastated by wars, required a financial injection which only women could actually give, as they were the ones that could avoid being recruited for the war, as they could not take part in the army. After the disaster of $216 \mathrm{BC}$ we detect the advent of a constrictive legislation against opulence and luxury against women, as well as restrictions on a likely female financial administration, who would have probably seen their wealth increase significantly by the inheritances received from their male relatives perished during warfare.

Some of these laws, senatus consulta and trials against women who exceeded their identity restrictions, occurred in times of confrontation against the Carthaginians: laws against mourning in $216 \mathrm{BC}$; the lex Oppia against the opulence of in $215 \mathrm{BC}$; taxes collected from Roman widows, coincidentally the most economically favored women from the war aftermath, in $214 \mathrm{BC}$; a senatus consultum against foreign worships supported by women in $213 \mathrm{BC} ;{ }^{23}$ the demands of the ediles asking matronae for financial support using their own dowry in $207 \mathrm{BC} ;{ }^{24}$ and so on. These laws were evidently looking for the control of women who, unexpectedly, had found a fissure in the Roman legal system that allowed them to invest in favor of the State thanks to the amount of wealth acquired during the mid-Republic. Following the performative method, it is 
noticeable how the discourse -imposition-reiteration-naturalization-, is performed until there is a rupture that those men who imposed such a message would have not predicted. In this regard, the absence of men of State motivated positions that were occupied by women who adding other attribute to their identities, rather than only maintaining the one of gender, that is the characteristic of State investors, which also by repetition was finally naturalized by themselves. Since men in power needed financial support from the fortunes held by women who lost men relatives during warfare, they were allowed to add this attribute to their female identity, thus naturalizing those empowering finance injections. As this way of public participation was normalized, it is reasonable to suggest that this economic participation would originate the following interpretations as further intrusions into the political arena, since financial expertise could be understood as a non-institutional power that welcomes the realities of investors such as women..$^{25}$ The response of men in power will come in the form of tools and instruments in order to redirect the political discourse, thus the legal constrictions against women set out above. On the other hand, and although we glimpse certain participation of women in the form of financial investment, we could contemplate the possibility of them being acquiring economic and political knowledge and skills, hence making it necessary for men to maintain the tutela system for not squandering the fortunes collected by women in times of a palpable social unrest.

Therefore, by applying a performative approach, we will be able to envision that the elaboration of a large number of laws that aim at restricting a financial management made by women, had as a main goal to restrict the power resulting from these sporadic, but needed capital injections. In order to do so, men will successfully try to retrieve and improve a performative discourse that relegate women to the background again; nevertheless, this rupture-subversion of the message will always be there for us to find it.

Individually as well as collectively, the development of women as administrators of their inheritance, dowry, and wealth became a reality as centuries went by. Indeed, the fluctuations regarding the women's economy and their participation all over the Republic, will create a new identity that will be welcomed by other women whose diligence and financial self-sufficiency has arrived to us in the ancient sources in the shape of letters written by the well-known lawyer and prosperous politician Cicero, as his wife Terentia was a regular matrona capable of handling such responsibilities, rather than one of a kind. ${ }^{26}$ Great social changes escalated during these times, produced mainly thanks to a variation produced within one of the most common tools of perpetuation, marriage, as it commonly changed into a sine manu form, thus a

25. S. Medina Quintana: Mujeres y economía en la Hispania romana: oficios, riqueza y promoción social, Trabe, Oviedo, 2014; on Roman women from Hispania who worked and invested their wealth as well as their role as evergetae or State investors.

26. C. FERRER-AlCANTUD: «La mujer romana y el ejercicio del poder a través del control de las finanzas: el caso de Terencia, esposa de Cicerón», Potestas, vol. 7, Castellón, pp. 5-25. 
more freed outline of this performative instrument. Moreover, changes concerning the weakening of guardianship took place in an environment where women could chose personally their tutor, as well as collective and associative actions embodied by women -e.g. those who handed over a social revolt in 195 BC against the Oppian law until it was repealed-, are realities that must be taken into account in order to explain Roman women's representativeness. In this regard, maintaining archaic institutions such as the muliebrum tutela, as well as the elaboration and purpose of restrictive laws against women's financial administrative skills, make us believe that these were measures that men with institutional power imposed, as a performative recycled message, in order to avoid the possibility of unrestrained women, however remote it might have been. Instead, reinforcing these measures assured that the main goal performativelly imposed in every Roman women's life, that is procreating, will be preserved endlessly. Women invading power could have ended with this patriarchal objective, hence men attempted to maintain each display and expression of power for themselves by tools of perpetuity and performative instruments that foster the binomial opposition of two sexually -in fact, culturally, thus socially- differentiated genders.

In order to give readers another example of what a performative fabricated message can do as well as reveal, we will add another performative illustrations to the above mentioned legal measures regarding tutela and the laws of wealth restriction, understood both as tools of social control disguised as a protection measure over the fortune of women. ${ }^{27}$ In these sense, there are another kind of performative instruments that concern language, as we said earlier: there were words and conceptions that reinforced men as guardians of what was actually women's inherited wealth, expressions that were part of any female gender identity, such as infirmitas sexus, leuitas animi, or imbecillitas. Undeniably, language is a tool which endorses performative messages and acts, as words can be used as weapons and these follow a performative pattern of impositionrepetition-normalization through which every term is implanted within the Roman society by reassigning it to an ancestral origin, the mores. Thus, these words will be perpetuated by granting them an ancestral custom and tradition, which in this case refers to women as incapable of doing anything else by staying at home, getting married and being fertile..$^{28}$ Eventually, a discourse of a not originally characteristic female weakness will sadly survive until today.

By focusing on the subversions rather than following the Roman propagandistic paradigm of women's identity, we observe their presence and involvement in leading events and political changes of the Republic. In spite of Livy's use of exempla in order to force women to follow an extinct and perhaps never existing behavioral feminine pattern, provides us the keys for a recognizable performative speech that concerns domesticity, pudicitia, and devotion. In this

27. Gaius, Inst., 1.11 .3

28. Cic., Pro Murena, 12.27 
regard, we are capable to spot all silenced women that Augustus was trying to restore in times where these women were only an idealized version against the reality of several actual and politically involved women, a real model which he yet aimed to suppress. To put it briefly, performativity allows us to recognize that those women who had survived through history without uttering a word -as we do not have their own voices recorded in sources-, are nothing more than deceptive pictures, fictitious realities created with the aim to enable socio-biological reproduction in an setting where civil wars had depleted the population of the new Rome of Augustus.

\section{CONCLUSION}

All in all, we hope that researchers will find this method useful, as they will be able to perceive the main performative discourse shaped like an iterated message, which relies on a fabricated identity that is gradually repeated and performed by both, individuals and every collective. In this sense, we should accept that social identity patterns within Roman culture were actually tall tales that have been perpetuated over time and cloaked as tradition along with the so-called mores. The few exempla we have analyzed throughout this paper are only an excerpt of what this method could unveil. We hope this research to eventually disclose a well-founded ratio of actual participation, public visibility, and financial involvement of women in what had been usually seen as "male affairs", according to a performative and entailed message that excludes the feminine Other. It is our belief that this approach will give women their voices back, enabling those who held power somehow to become part of a more inclusive History, and finally allow us to be capable of define their means, interests, and involvement in relation to the hectic last events of the Roman Republic.

Coveted Roman standards that had their beginning far away in time, still stand today because of the insistence of many concerning the maintenance of a story -not History- originated long ago and which ultimate end was to constrain minorities within an illusory but eternally emulated society. In the end, a performativity method could even measure their contribution in the configuration of the Principate's social role models - not only those of the matronae, but also their interrelation and effects on other identities-, thus finally clarify how important they actually were as a tangible part in History.

\section{BiBLIOGRAPHY}

Alexandridis, A. (2009): «Neutral Bodies? Female Portrait Statue Types From the Late Republic to the Second Century CE», Material Culture and Social Identities in the Ancient World, Hales y Hodos (eds.), Cambridge University Press, Cambridge, 2009, pp. 252-279. 
Butler, J. (1986): «Sex and Gender in Simone de Beauvoir's Second Sex», Yale French Studies, no. 72, 1986, pp. 35-49.

- (1988): «Performative Acts and Gender Constitution: An Essay in Phenomenology and Feminist Theory», Theatre Journal, Vol. 40, no. 4, pp. 519-531.

- (1989): «Foucault and the Paradox of Bodily Inscriptions», The Journal of Philosophy, Vol. 86, no. 11 , pp. 601-607.

- (1997): The Psychic Life of Power. Theories in Subjection, Stanford University Press.

- (1999): Gender Trouble: Feminism and the Subversion of Identity, Routledge, Londres.

- (2011): Bodies That Matter. On the Discursive Limits of "Sex", Routledge, Nueva York.

Derrida, J. (1978): Writing and Difference, The University of Chicago Press.

GARDNer, J. (1987): Women in Roman Law E Society, Croom Helm, Londres.

Gleason, M. W. (2008): Making Men. Sophists and Self-Representation in Ancient Rome, Princeton University Press.

Goffman, E. (1993): La presentación de la persona en la vida cotidiana, Amorrortu, Buenos Aires.

Gunderson, E. (200o): Staging Masculinity. The Rhetoric of Performance in the Roman World, The University of Michigan Press, Ann Arbor.

Hodos, T. (2006): «Local and Global Perspectives in the Study of Social and Cultural Identities», Material Culture and Social Identities in the Ancient World, Hales y Hodos (eds.), Cambridge University Press.

Levinas, E. (2007): Totality and Infinity, Duquesne University Press, Pittsburgh.

Mattingly, D. J. (2011): Imperialism, Power, and Identity: Experiencing the Roman Empire, Princeton University Press.

WiLDE, O. (1905): Intentions, Bretano's, Nueva York.

Williams, C. A. (1999): Roman Homosexuality: Ideologies of Masculinity in Classical Antiquity, Oxford University Press, Nueva York.

Medina Quintana, S. (2014): Mujeres y economía en la Hispania romana: oficios, riqueza y promoción social, Trabe, Oviedo.

Ferrer-Alcantud, C. : «La mujer romana y el ejercicio del poder a través del control de las finanzas: el caso de Terencia, esposa de Cicerón», Potestas, vol. 7, Castellón, pp. 5-25. 